AWEJ for Translation \& Literary Studies, Volume 5, Number3. August 2021

DOI: http://dx.doi.org/10.24093/awejtls/vol5no3.13

Pp.185-202

\title{
Moroccan Berber Patrimony: An Aptitude for Transnationalism and Universal Coexistence
}

\section{Sofian Herouach \\ English Department}

Faculty of Arts and Humanities

Dhar El Mehraz, Sidi Mohammed Ben Abdullah University, Fes, Morocco

Received: 7/19/2021 Accepted: 8/27/2021 Published: 8/30/2021

\begin{abstract}
Moroccan Berbers/Imazighen have undergone centuries of cultural and economic exchange with different foreign powers that crossed to the Maghreb throughout history. Following a significant process of interaction and interchange, the mode of life of the indigenous people has been significantly shaped. This might explain a great deal of present-day socio-cultural diversity enjoyed and exercised in Morocco. The present study aims at investigating aspects of Berber's interaction with the various populations that landed on North Africa throughout history. The research study builds on the following question: how does the Berber heritage enhance an outlook of transnational exchange and cooperation? The study reaches out the conclusion that Moroccan Imazighen had cohabited and coexisted with different races since immemorial times. Moreover, the study infers that such a longstanding tradition of borderless socio-cultural and economic exchange may serve as a background legacy for present-day Moroccan transnationalism and universal coexistence.

Keywords: Amazigh heritage, diversity, global exchange, Moroccan Berbers, universal coexistence

Cite as: Herouach, S. (2021). Moroccan Berber Patrimony: An Aptitude for Transnationalism and Universal Coexistence. Arab World English Journal for Translation \& Literary Studies 5 (3) 185-202. DOI: http://dx.doi.org/10.24093/awejtls/vol5no3.13
\end{abstract}




\section{Introduction}

Due to its Mediterranean strategic location, the Maghreb has been exposed to foreign impact since immemorial periods. As indigenous inhabitants, the Berbers were influenced by the culture of the several civilizations that landed on North African territories since early history. In this interest, Howe (2005) held, "Through the centuries, they [Meaning Berbers] were overrun by foreign invaders: Phoenicians, Carthaginians, Romans, Vandals, Byzantines, Arabs and the Europeans who have left their marks to varying degrees" (p. 58). The first people with whom North Africans came in contact were Phoenicians. Upon the collapse of Phoenicia, Carthage developed into an empire and exercised significant influence in the Maghreb. Later, the GrecoRomans emerged as undisputed masters of the Mediterranean. Having displayed military, intellectual and economic potentials, the Greeks had an unprecedented impact on the life of the natives. The Romans took on the Greeks, adopted their manners, and learned their sciences. On their part, the Romans, as soon as they held hegemony of vast territories of North Africa, have spread the Latin mode of life among Imazighen to the extent that several amongst them were Romanized and emerged as the elite class of the Roman society.

In terms of creed and religion, the Maghreb has hosted and practiced many forms of worship such as Paganism, Judaism, Christianity, Islam, and heretical movements such as Barghwatan and Kharijism. The following study is an attempt to justify the diversity and openmindedness of Moroccan Berbers by shedding light on some patterns of their socio-cultural cohabitation and interchange with the various populations that footed North Africa since immemorial times. The research is important in the sense that it explores the Berber legacy, whereof it derives a comprehensive approach that enhances universal cohabitation. Meanwhile, digging out and reviving the Berber tradition helps in subverting predominant ideologies that may preach extremism and narrow-mindedness.

An important motive behind the choice of conducting this study is a crucial need for a background legacy that nourishes ideological toleration and accepts cultural and belief differences. Unlike some religiously-based movements that may incite violent behaviors against belief and cultural differences, Moroccan people- though referred to as Muslims- are inherently tolerant. They retain a spirit of coexistence inherited since immemorial times. The research aims at displaying how does the Amazigh patrimony tend to embrace a vision of worldwide cooperation and coexistence. It is hypothesized that the moderateness of Moroccan Islam is referred to the predominance and preservation of Moroccan cultural heritage. Nowadays, there is more emphasis on Moroccanity and Moroccan patrimony, rather than the identification with many Muslim countries where Islam is applied intensively. The following sections explore some aspects of Berber economic and cultural exchange with the different foreign intruders that were attracted to the Maghreb and what influence this course line exchange exercises on the present-day Moroccan character.

\section{A Tradition of Borderless Exchange}

Some writings about the history of the Maghreb claim that Imazighen have always been inclined towards disorder and anarchy. Accordingly, their conformity to rules has always been volatile, and they have always threatened social and political stability. Authors such as Montagne 
(1973) is an example that advocates such negative descriptions of Imazighen. He believes that Berber society has been led by a tribal system, characterized by internal feuds and conflicts (Montagne, 1973). He put, "They [Meaning Imazighen] are no more than collections of heterogeneous elements, gathered from the four corners of the horizon and having merely a name in common" (Montagne, 1973, p. 28). In other words, he tended to describe Imazighen as a lineage without any founded ancestry. However, Montagne might have been influenced by the political reality of his country. It is obvious that this author was a French orientalist and wrote at times of French colonization. Colonialism took the mission of civilizing the colonized as a pretext to fulfill colonial outcomes. Therefore, representing the target population as disordered and uncivilized in writings and studies might have been guided by colonial intents. Thus, it could be assumed that the author's underestimation of the Berber society was conditioned by colonial objectives. Contrarily to these claims, Imazighen were a complete ethnicity and have lived centuries of systematic rule and geographical unity. For instance, Weitzman (2011) stated,

The numerous manifestations of being Berber, including the existence of various forms of a single language, social organization, territorial cores, and daily praxis were durable enough to enable the inclusion of Berbers within the broad category of pre-modern ethnies expounded by Anthony Smith (p. 13).

According to this saying, one of the founders of the interdisciplinary field of nationalism studies, the sociologist Anthony David Smith, admits that Imazighen are a pre-modern nation. That is to say, they have always been an ethnicity with a certain social and political system. In this regard, the renowned sociologist Ibn Khaldun held, "They belong [Meaning Imazighen] to a powerful formidable, brave and numerous people; a true people like so many others the world has seen-like the Arabs, the Persians, the Greeks and the Romans" (as cited in Rouighi, 2019, p. 79). Moreover, Imazighen have demonstrated throughout history tactful political and social administration. Models in this field are Sheshonk I who conquered Pharoah Egypt in the tenth century BCE; Masinissa the king of Numidia; his grandson Jugurtha who challenged the Roman empire; and Juba II, the ruler of Mauritania Tingitana (Present-day North Morocco and a part of west Morocco, including Volubilis as the administrative capital). These are unforgettable figures in Amazigh memory. They are luminaries testifying to periods of glory, social unity, power, transborder sociocultural fertilization, and economic cohabitation. Regarding the last point, Imazighen have manifested a remarkable spirit of coexistence with different populations coming from different corners of the world. For example, history proves of a long process of Moroccan Imazighen interchange with different races and civilizations. From BCE periods to modern times, Imazighen had interacted with diverse peoples such as the Phoenicians, Carthaginians, Greeks, Arab Muslims, and occidentals. The chain of Moroccan borderless exchange and cooperation has been ongoing ever since, and it is presently extending to more areas of the world such as sub-Saharan Africa, Asia and Asia minor countries. The following sections reveal aspects of Imazighen worldwide socio-cultural and economic exchange across history.

\section{Imazighen and Phoenicians}

Phoenicians ${ }^{1}$ were a people that inhabited very early present-day Lebanon and northern Israel. They were very famous for their navigating powers. Unafraid of the mysteries of the sea, they 
dared to sail beyond the Mediterranean scopes across the Atlantic Ocean towards England and Ireland. Guided by an invincible power of expanding trade, the Phoenicians sailed far and wide, even beyond the Mediterranean's traditional safe limits of the Pillars of Hercules and into the Atlantic (Cartwright, 2016). They followed and discovered the lands that produced metals. They explored Spain that was a source of acquiring silver; they raided Africa to extract gold and they explored Sicily Isles for tin. At some point of their line seafaring journey in the twelfth century, they followed the Mediterranean coastal line and reached Northern Morocco. The natives welcomed them for trade exchange because as Chafik (2005) held, "They [Meaning Phoenicians] came as peaceful visitors and as guests" (p. 19). Over time, the Phoenicians were interested in enlarging economic deals with the indigenous populace by establishing commercial centers and bases. The first settlement they built was Lixus, present-day Larache in Northern Morocco. Constructed in about $1100 \mathrm{BCE}$, Lixus is considered one of the most ancient world heritages, and "was central to early Phoenician trade in Atlantic Morocco" (Markoe, 2000, p. 187). In this regard, Abun-Nassr (1971) stressed, "The Phoenicians bartered with the indigenous people manufactured goods for victuals and items suitable for resale, such as hides and the ivory of elephants" (p. 13).

From the ports of Lixus, the Phoenicians established further trading capitals across the Maghreb. After Lixus, "they have established coastal trading posts at Tangier and as far south as Essaouira" (Howe, 2005, p. 58). Essaouira or Mogador, dating back to the sixth century BCE, was one of the main settlements of the Phoenicians (Saithip, 2014). Moreover, it was recognized by UNESCO as an exceptional example of a late eighteenth-century fortified town, built according to the principles of contemporary European military architecture in North African context (UNESCO, 2001). Since its foundation, it has been a major international trading seaport, linking Morocco and its Saharan hinterland with Europe and the rest of the world (UNESCO, 2001). The Phoenician architectural touch as well as that of the Greeks after them survives to the present day in Moroccan Mogador. Markoe (2000) affirmed, "Ceramic finds which include a large quantity of red-slip ware sheds with several bearing Phoenician inscriptions together with Greek (Attic and Ionian) amphorae and Cypriot pottery are strong sign of the significant presence of the people in Mogador" (p. 188). Because of the flexibility of economic exchange and cultural toleration of the local inhabitants, trade prospered between natives and Phoenicians. The immediate economic flourishing of the city may be regarded as a direct result of the underlying spirit of collaboration between these populations. In a word, Phoenicians must have exercised significant influence on the socio-cultural structure of the indigenous people. After them, the pace of establishing commercial and cultural relations continued. Phoenician's rivals, Carthaginians, elaborated on trade and commercial exchange with the natives of North Africa.

\section{Imazighen and Carthaginians}

Carthage was founded by the immigrants of Tyre, one of the most important Phoenician centers. Tyre, a Lebanon city and a world heritage site, was one of the most strategic locations of Phoenicia whereof Phoenicians departed their great exploration through the Mediterranean. It was a powerful city that ruled the seas and founded prosperous colonies such as Cadiz and Carthage (UNESCO, 1984). The Phoenician territories were geographically and politically disunited. Phoenicia was politically organized in city-states and geographically identified to have inhabited roughly presentday Lebanon and North Israel; whereas, Carthage is tackled in historical records as an independent 
nation, located in present-day Tunisia. In the sixth century BC, Carthage was the most prosperous city of the ancient world. Kagan, Ozment and Turner (1987) confirmed, "Carthage developed quickly into a center of a vast expanding empire in the $6^{\text {th }}$ century BC, seizing Malta, Sardinia and West of Sicily" (p. 120). It reclaimed all the North African lands previously possessed by the Phoenicians. However, Carthage intended trade with its colonies more than it aimed at military occupation.

Carthage was oriented towards setting up economic relations and "was satisfied to cultivate friendly relations with the Berber chiefs that included intermarriage between them and the Punic aristocracy" (Abun-Nassr 1971, p. 20). Moreover, Elissa identified by the name of Didon, the founder of Carthage city in 814 BC aimed as Chafik (2005) asserted, "to a consolidation of earlier relations between the Berber pastoral productive society and the Carthaginian delegations of traders and craftsmen" (p. 19). In other words, the Carthaginians seized their predecessor's Phoenician colonies and followed a policy of economic exchange and commercial transactions. They elaborated on the older Phoenician foundations such as Utica in Tunisia and Lixus in Northern Morocco. For instance, these centers became considerable settlements of international commerce, "serving as victual stations along the coasting routes to Spain and Egypt, with economic significance of their own as centers for fishing and as posts for trade with the peoples of the interior" (Oliver, 2008, p. 126). On the other hand, the Carthaginian trade was extended to other Mediterranean coastlines and centers "such as Ksar es-Sghir on the strait of Gibraltar and Essaouira and Tangier and perhaps Asila on the Atlantic coast" (Pennell, 2003, p. 8). However, economic relations flourished especially at the base of Mogador. This town in particular prospered further during the presence of the Carthaginians especially it was a "source of one of the most valuable commodities in the ancient world: purple dye" (Pennell, 2003, p. 8).

There has also been an influential interaction between the natives and the Carthaginians in terms of culture, language, tradition, and belief. One important influence was the adoption of the Carthaginian Goddess Tanit or Tinnit by Imazighen. For instance, Sadiqi (2014) stressed,

With the coming of the Phoenicians, the indigenous Berbers started to adopt their institutions, language, attire, and religions, especially the cult of the great goddess of Carthage: Tanit; the various chains, collars assorted with crescent-shaped pendulums with the sign of Tanit engraved in them, pearls, stones, pendants, and granulated ear-rings allow us to imagine how women (probably belonging to the elite in the Romanized Moroccan cities) lived and what fashion they wore during those times. (p. 44)

On the other hand, Punic ${ }^{2}$ language influenced the Berber alphabet Tifinagh ${ }^{3}$ especially during the emergence of Berber kingdoms such as Numidia. In this regard, Fage (1978) confirmed, "Punic was employed as the official language of the Numidian kingdom, as is shown by monumental inscriptions and coin legends" (p. 184). Weitzman (2011) added, "There was a mixing of Punic and Berber in certain areas and among certain societal groups as part of larger, social, political and cultural dynamics then at work" (p. 18). This must have led to a significant linguistic fusion of Punic and Tifinagh; henceforth, an outstanding socio-cultural and intellectual interchange. Moreover, many Numidian cities were modeled on the Carthaginian architecture after the 
foundation of Numidia by Masinissa. For example, Hippo Regius (Annaba in Algeria), Lepcis Magna (Leptis in Libya) and Thugga and Sicca (Tunisia) are clear models that adopted a Carthaginian architectural style (Fage, 1978).

The Berbers, not only were they influenced by Punic lifestyle but they also became the upholders of neo-Punic language during the subsequent centuries (Raven, 1993). That is why perhaps, we still touch on similarities between Punic and Tifinagh scripts. It must be a consequence of a long process of linguistic and cultural fertilization. In addition, it is held that the Carthaginian arts and sciences were inherited by the Berbers. This inheritance included as Niebuhr (2009) asserted, "The precious libraries that were handled in 146 BC to Masinissa's son Micipsa" (p. 315). Moreover, several Imazighen notables have left a written legacy in Punic. An important example is a Numidian king, Hiempsal II who is held to have written a history of his country in Punic language (Fage, 1978). Consequently, it is normal that Tifinagh bears patterns of resemblance with Punic script. In a word, the Maghreb has undergone another stage of sociocultural and intellectual interbreeding of more influence than that exercised during the settlement of the Phoenicians. Maghreb and Moroccan attire, life style and traditions have been further shaped by dealing with the Carthaginians. However, external impact continued ever since by the subsequent civilizations which followed the Carthaginians'.

\section{Imazighen and Greeks}

Because of the Phoenician exploration of vast lands, North Africa was displayed and drew the interest of various powers. Around the sixth century BC, Greece emerged as an unnegotiable force not only militarily but also intellectually. The Greek civilization was famous for military power as well as for mental philosophical and scientific speculations. Greece is generally conceived to have enjoyed its golden age from the $6^{\text {th }}$ to the $4^{\text {th }}$ century BCE. During these times, it emerged as the most intellectual nation that the ancient world ever perceived of. It is the period that has given us the great monuments, art, philosophy, architecture, and literature which are the building blocks of modern civilization. After their occupation and ruling of Egypt for long decades, the Greeks moved to North Africa. Greek interest in the Maghreb started in about 630s BCE, in Libya. In 631 BCE, the Greeks occupied an inland site, Cyrene (Present-day Cyrenaica), that was shown to them by the natives (Violatti, 2010). Cyrene was marked by the presence of abundant spring and soil fertility that the Greeks noticed. Thus, they launched plans of vast land cultivation. In addition to the export of corn and horses, Cyrene was famous for an indigenous plant, Silphium, a herb used for nutritional and medical purposes. In this regard, Fage (1978) put,

In the first place, the fertility of Cyrenaica was such that it yielded agricultural produce; in the second place, trade with the Libyans of the interior developed to unpremeditated importance; this was due to the discovery of the mysterious plant called in antiquity silphion, whose root served a variety of culinary and medicinal purposes. (p. 110)

As a consequence of both, the fertile lands and the peaceful spirit of the inhabitants, agriculture and economic relations thrived in these Libyan centers, especially in the fifth century BC. For example, it is held that agricultural products of crops, vegetables, and fruit returns were abundant that it transcended the local demand to be transported to the Greek colonies and beyond. 
A set of mosaics from a villa at Thabraca shows agricultural estates still prospering in the fifth century BC, with highly efficient land use: there olive trees grow under palms, figs under olives, vines under the fig trees and the vine row. (MacKendrick, 1980, p. 91)

The welcoming spirit of the Berbers led not only to trade progress but it led also to mutual blood and marriage recognition. Fage (1978) confirmed, "By influence of settlement in the Libyan lands, it became quite normal for Greek men to take Libyan wives" (p. 115). Oliver (2008) contended, "There were constitutional regulations by Ptolemy after $322 \mathrm{BC}$ which include the provision that the children of Cyrenaean men by Libyan wives should have Greek citizen status" (p. 115). This enhances the proposition that such Greco-Libyan marriage and intercourse were common. As a consequence of this commercial and marriage exchange, further trans-cultural encounters and assimilations, particularly in terms of religious beliefs ensued. Differently to the Berber adoption of the Carthaginian goddess Tanit, it was now the Greeks as foreigners who took on the native's religious forms such as the worship of the Libyan God Ammon.

Another cult which the Greeks adopted from the Libyans was that of a god whom the Greeks called 'Ammon', a version of the Egyptian god Amun-Re', in origin a fusion of the sun-god Re' with the ram-god Amun, who was often represented as a ram-headed man. (Fage, 1978, p. 115)

The principal center of the cult of Ammon temple exists in the Oasis of Sewa, in Egypt. It is held that the temple was frequently consulted by Greeks from Cyrenaica and even from further afield, as by Alexander in $332 \mathrm{BC}$ (Fage, 1978). In a word, the aforementioned patterns of the GrecoLybian exchange are an evident image of the North-African socio-cultural interbreeding and coexistence with the Hellenistic world. Although the Greek occupation didn't last for long, the Romans had consolidated Hellenistic principles in the Maghreb; henceforth, an unprecedented intellectual outbreak of prominent Berber figures in various fields. Numerous Imazighen emerged as the leading intellectual elite of the Roman cultural and political life.

\section{Imazighen and Romans}

Besides Greek influence, Rome exerted significant cultural, political and economic impact on Berber's lives. Upon the coming of the Romans, North Africa has been ripe and ready for further assimilation. Abun-Nassr (1971) asserted, "The Berbers showed great readiness to accept the civilization and the political institutions of Rome" (p. 36). Not only was there an effective interaction between the natives and the Romans but the Roman civil and military power comprised mainly of the African stock

Whether we call North Africa's native inhabitants Berbers, Punics, Numidians, or Africans, it is clear that under Rome, there were various degrees of co-optation and interaction, and that the vast bulk of the Roman population there, both civil and in the army, was of African origin. (Weitzman, 2011, p. 19)

The Berbers welcomed and adopted Roman manners; especially the Romans didn't display racial, military or coercive intents towards the natives and "were remarkably tolerant of the Berber 
religious cults, be they indigenous or borrowed from Carthaginians" (Abun-Nassr, 1971, p. 36). Socio-cultural fusion between Romans and Berbers was much more profound than it was with their predecessors. For example, the remarkable traces and Roman ruins in Volubilis- located near the city of Meknes in Morocco- display strong signs of populace cohabitation. Founded in the third century BC, Volubilis served as the administrative capital of the Mauritanian kingdom (Mauretania Tingitana) and became an important outpost of the Roman Empire (UNESCO, 2008). Architecturally, Volubilis has got a splendid structure and a strategic position.

There was a city at Volubilis, where Punic inscriptions and archeological remains show that it was a big town in the third century BC (...), it is well supplied with water and well situated: on a plateau, overlooking a pass between the mountains. (Pennell, 2003, p. 8)

Many architectural patterns inherited still survive in this patrimonial town. Archeologists have found "monumental remains of a triumphal arch, a Basilica and numerous wealthy homes at Volubilis" (Howe, 2005, p. 59). Agriculturally, Volubilis was very fertile and productive with a "hundred olive presses have been found" (Pennell, 2003, p. 12). Moreover, it was significantly populated and it is believed that it was once home to 20,000 residents (Sinclair, 2017). It could be assumed that most of the inhabitants were natives but they were also an integral part of the Roman Empire. In other words, Volubilis, being a significant agricultural producer, must have connected the indigenous Moroccan populace with the Romans and transmitted along with trade, culture and traditions. For example, Stokes (2009) confirmed, "The Berbers of Volubilis and at other Roman sites throughout North Africa adapted to the Roman culture and combined local gods and beliefs with the Roman pantheon" (p. 116). Thus, a large percentage of Berbers have been gradually and progressively assimilated into the Roman culture over the long period of Roman rule in North Africa. About three centuries of economic and socio-cultural interchange, the Berbers were presented as an essential stock to the progress of the Roman Empire.

Nearly one-third of the Roman Senate in the 180s was of African origin, and shortly after that, Septimius Severus, born in Leptis Magna, a Roman Colonia in what subsequently came to be known as Tripolitania (Libya), became the first African-born emperor of Rome (AD 193-211). (Weitzman, 2011, p. 19)

Septimius Severus is an example showing the extent to which a racial fusion between Imazighen and Romans has taken place. Moreover, it displays how Rome involved many Imazighen as the ruling elite class of the society. Another example in this regard is the famous playwright Terence who initially reached Rome as a man of low social class to turn to one of the most popular Hellenistic artists. In this regard, Raven (1993) held, "Terence who initially reached Rome in the second century as a slave from the lower less-assimilated portions of the Berber population turned into one of the most admitted and educated Hellenistic playwrights" (pp. 122123). One of his famous quotes in his renowned play Heauton Timorumenos (the self-tormentor) goes as: I am human, and I think nothing human is alien to me (Terence, 2018). Terence's popularity was resumed during the Middle Ages and Renaissance times. He was included in Luther's works and his comedies were recommended to be taught at school for children. Luther

Arab World English Journal for Translation \& Literary Studies 
held, "Poets and playwrights portray the real world, Terence, homer and other poets were no lazy dog monks but saw how things are with real people" (as cited in Oberman, 1974, p. 106).

Terence aimed at transmitting different themes in a witty manner. From a literary perspective, he contributed along with numerous other intellectuals in leading the ground for Renaissance. Luther added, "I love Terence, for I see that it is good rhetoric to make a comedy out of a man sleeping with a maid than imagines what the father, what the servant, what the circle of friends says to that" (as cited in Oberman, 1974, p. 106). Another important figure is Juba II, husband of queen Cleopatra Selene II. Juba II was the ruler of Mauritania Tingitana 25-23 BC (King, 2020). Besides his reign skills, he was a highly respected scholar. He took an immense interest in research and knowledge. He spoke and wrote in many languages: Numidian, Latin and Punic. It is generally held that he authored several books in Greek and Latin on natural history, geography, agronomy, grammar, painting, and theatre. In this regard, Joseph (2003) asserted, "He developed into a true scholar whose chief motivation in life was the eternal quest for knowledge" (p. 15). Aside from his reign characteristics, he has been a model for literary innovation and scientific research. The American human rights activist Frank Joseph dedicated a book, 'The lost Treasure of King Juba, the Evidence of Africans in America before Columbus' (2003) to the ruling wisdom of Cleopatra and the intellectual life of her husband Juba II as well as his treasure library of Alexandria that contained shelves of precious ancient books and manuscripts.

He was truly happy and content only when studying, attending lectures or writing; fluent in Numidian, Latin, Greek and Phoenician, he was something of a genius publishing dozens of books on history, botany, geography, zoology, philosophy, poetry, grammar, painting, music, dance, sculpture and travel. (Joseph, 2003, p. 14)

Moreover, his enthusiasm and passion in knowledge were admired by numerous Hellenistic authors. For example, Pliny the Elder refers to him as an authority sixty-five times in the "Natural History' and in Athens, a monument was built in recognition of his writings (Elder, 1857). In a word, Juba II when appointed by the emperor Augustus Caesar as ruler of Mauretania Tingitana, had encouraged scientific research as an asset to democratic leadership. More importantly is that he engaged his wife Cleopatra II in his political leadership, a symbol of gender equity. She is held to have exercised considerable influence on his political decisions. Another figure, Masinissa, remains an unforgettable model for Imazighen. Masinissa (202-148) BCE managed to unite all the Berber-speaking tribes into a single nation. It was since his time that the name Numidia came into broad use. It referred to all the territories of Imazighen united under one political body. Also, having invented currency coins in his name had raised him to the state of Latin privilege and put him in the position of a true king. Schaar (2016) affirmed, "This intelligent, fearless and subtle man is shown in contemporary coins as a king in his forties or fifties, with sharp features, wide eyes, thick eyebrows, long hair and a pointed beard" (p. 16).

All in all, these Berber luminaries serve as iconic figures for modern Amazigh memory, providing tangible evidence of both Berber's deep-rootedness as well as their contribution to civilization building. On one hand, the aforementioned data show crystal clear that Imazighen weren't merely passive victims of ancient civilizations but contributed to the comprehensive 
process of urbanization culturally, architecturally, literarily, and scientifically. On the other hand, these arguments reflect Berber's aptitude for global interculturalism and universal coexistence.
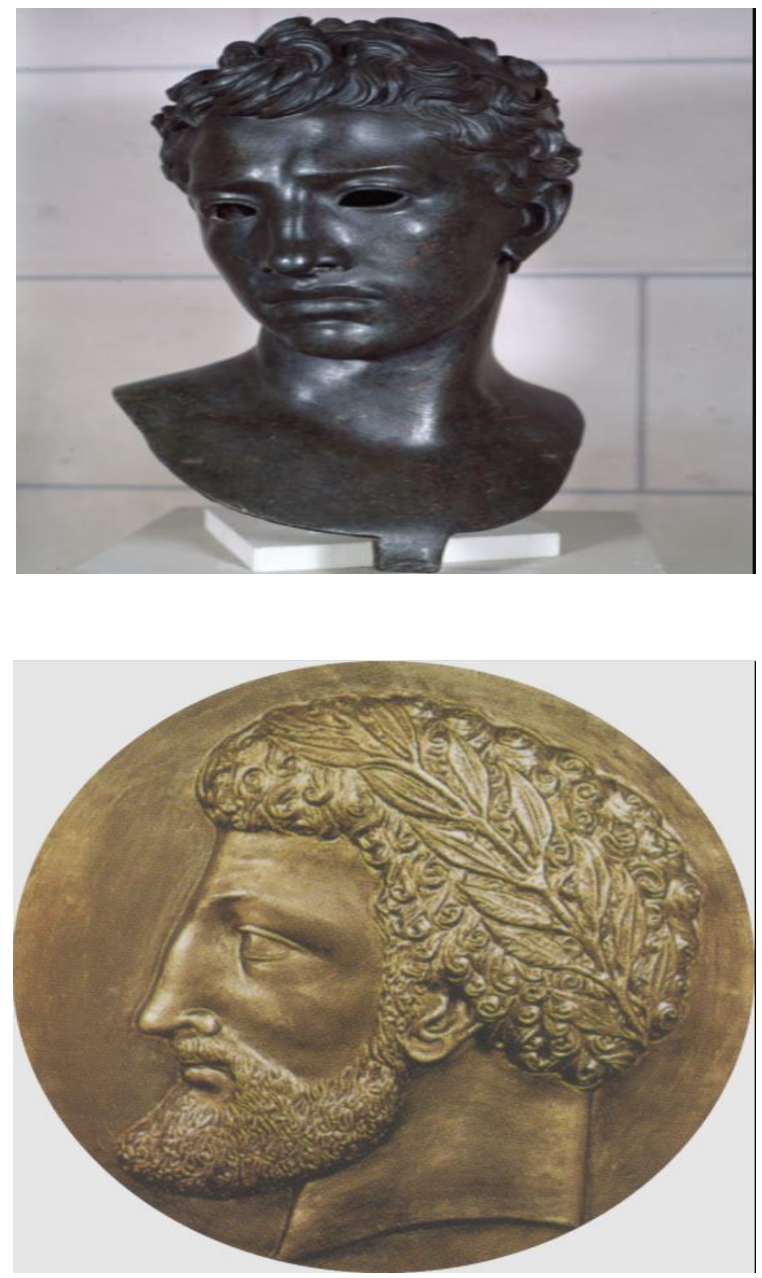

A bronze bust of Juba II as a young man, created sometime in the 20s BCE. The bust was found in Volubilis, the western capital of Mauretania during the reign of Juba II (Foliot, 2020).

Coin depicting Masinissa, the first king of Numidia (Numidix, 2017).

\section{Imazighen Religious Flexibility}

Imazighen are also distinguished by a tradition of outstanding flexibility in terms of religiosity and belief. Throughout history, Imazighen have not only practiced economic and cultural exchange but they have also embraced different faiths that were brought to them by guest-intruders. Berber history has gone through paganism, Judaism, Christianity, and Islam. Berbers not only did they manage to co-exist with these forms of faith, but they also contributed in spreading them. In other words, Imazighen tended to accept different religions, emerging as leaders of religious movements and authors of theological exegeses. Weitzman (2011) stressed, "As has always been the case throughout North African history, Berbers/Libyans/Punics/Africans could be found in all camps, as martyrs, saints, bishops, leaders, rebels, etc.” (p. 20). Religion has been regarded for Imazighen as a legacy of reinforcing human values. The Berber religious history has gone through significant diversity and reflects a tradition of freedom of worship. In this respect, Abun-Nassr (1971) affirmed, "The native Berber cults and the Semitic Gods introduced by the Carthaginians were Arab World English Journal for Translation \& Literary Studies 
worshiped side by side with the gods of the capitol" (p. 37). That is to say, religion has not been of any extreme sacredness to the lives of the Berbers; whereas, it has been tackled often as a means for pragmatic ends. Several times throughout history, Berbers complied with religious beliefs for merely political and social security and not for purely faith convictions. During the Roman rule in North Africa, the Berbers "considered it advantageous to worship as many divinities as possible in order to secure the greatest degree of protection" (p. 3). Even when they converted to Judaism and Christianity, their religiosity didn't stand for extremism.

Many of the Berbers had been converted to Christianity from Roman Egypt, mostly along the coastal belt, but Christianity never appeared to have taken a very firm root (...), some Berbers too were converts to Judaism which, like Christianity didn't take a strong root. (Fyle, 1999, p. 30)

On the other hand, Imazighen welcomed widely the Christian faith especially when the latter preached universal values. Sadiqi (2014) held, "The Berber indigenous populations gradually adopted Christianity throughout the third and fourth centuries, as well as the Roman mores, customs, and language" (p. 43). When the Roman empire launched a policy of persecuting Christians, there emerged leading Berbers who resisted that persecution in the name of true Christians like Tertullian, "a tiny defender for the Christian faith" (Frend, 2000, p. 116). Tertullian represented the Christian dissenters from the Catholic Church as their intellectual leader, defying the ecclesiastical authority of the bishops and forcing the church into a simple rendered brotherhood community of saints. He believed that every Christian belonging to church has the right to administer its sacraments, and not be dominant by a small religious oligarchy of the clergyman (Abun-Nassr, 1971). Such resistance to the Catholic Church assumed implications of emancipation from religious fetters; henceforth, a tendency towards social and individual freedom. The underlying themes of Tertullian discourse sound similar in outcomes to the reformation movement premises of the sixteenth century initiated by Martin Luther as well as to the English reformation led by Henry VIII, king of England. These movements resented the intervention of clergymen to control believers' faith or mediate between them and the Gods.

\section{Imazighen and Arab Muslims}

On their part, Arab Muslims have influenced significantly the lives of the natives. Nowadays, Morocco, constituting the largest population of Imazighen inhabiting North Africa, is considered a Muslim country. The Berbers had initially raised against the wave of Islam because the Arab Muslims at first, having assumed a heaven mission, had carried objectives of spreading the call coercively.

Arab conquerors came imbued with a universalist message and worldview that left no room for autonomous existence of the mostly nonmonotheistic Berber tribes, as they did not belong to ahl al-kitab (People of the Book) and thus could not receive protected dhimmi status. Their choices were stark: accept Islam, be enslaved, or submit to the sword. (Weitzman, 2011, pp. 22-23) 
Consequently, Imazighen faced this ideology by facing its pretenders and messengers. Moreover, Arab Muslims, especially the Umayyads, didn't show any mercy face to the natives even when Imazighen had relatively recognized Islam. Thus, Berbers faced them at first with war especially with two hero battles: Kusaila ${ }^{4}$ and Dihya ${ }^{5}$. Later, Imazighen employed different techniques of resistance. This was manifested in the heretic movements of Kharijites and Barghwatans. Kharijism is a movement conceived to oppose the choice of the ruler on the basis of race and inheritance and it stipulates that the leader has to be just. A famous Kharijite movement was led by Mayssara al Matghari in Moroccan Tangier in 739-740 against Arab Umayyads. On the other hand, Moroccan Barghwatans issued a version of Islam of their own to protect themselves from Umayyad despotism. These movements were adopted to face religious authoritarianism and Arab Umayyad Islamism.

Yet Imazighen had started later manifesting signs of accepting Islam when it was less intense and when the Berbers themselves emerged as upholders and Emirs of the call, like Moroccan Almoravids and Almohads. After the Umayyads, the call of Islam by later leaders took relatively peaceful forms. After a century of conflict and wars against Arab Muslims, mainly the Umayyads; the Berbers started converting to Islam in large numbers. For example, Idris I- assuming descent from the prophet and fleeing the Middle East riots after the rest of his family was massacred by the Abbasids- sought shelter and "found refuge among the Berber Awraba tribe who lived near Volubilis, where there seems to have been a Kharijite influence" (Pennell, 2003, p. 30). Despite the oppression the Umayyads led in the Maghreb, the Berbers welcomed Idris when he came asking refuge as a victim of the collective persecution of the Abbasidds. They recognized him as Imam and leader. Pennell (2003) asserted, "He [Meaning Idris I] took a local woman as a concubine and began to build the nucleus of a petty state" (p. 30). After him, his son Idris II was proclaimed sovereign at an early age of eleven years old after his father's death.

Around two centuries later, however, the leadership in the Maghreb and beyond was transmitted to the Berbers. Examples of these powerful ruling dynasties and their states that turned into empires are Almoravids and Almohads. For example, Islam was a major motive that led these two dynasties to rule states and construct empires. When Berbers themselves emerged as commanders of faith like Almoravids and Almohads, they believed it their turn and mission to spread Islam, supported by a firm policy of military and territorial expansion. Therefore, Berbers themselves played a major role in the spread of the call in Morocco, throughout the Maghreb and in Spain. In a word, Imazighen tended to respond to different religions pragmatically. Being initially pagans, they later embraced different faiths such as Judaism, Christianity and Islam. In other words, they coexisted with different religions brought by foreign powers according to different needs. Morocco, a major country in the Maghreb, has inherited that spirit of coexistence and has been involved in an ongoing process of borderless cultural, political and economic exchange. This worldview approach has been reinforced in the twentieth century with European neo-colonialism effects. Additionally, Morocco's transnational visions are being presently extending to MENA regions, Israel, subSaharan Africa and Asia.

\section{Discussion}

Arab World English Journal for Translation \& Literary Studies 
Moroccan history has demonstrated a longstanding tradition of transnational economic and socio-cultural exchange. Morocco, though considered a Muslim country, is disinclined to abide by extremism. On the contrary, the majority of its populace is far away from abiding by any strict interpretation of religion. That is because Moroccans have undergone stages of borderless interculturalism and retain a rich recorded tradition of cultural diversity and freedom of religiosity. Berbers were initially pagans, with each sect believing in its own deity. Having interacted with the Jews and even intermarried with them, many Imazighen converted to Judaism. After the Phoenicians and the Carthaginians, many Berbers turned to believe in Roman deities and adapted to the Roman mode of life. For example, Volubilis is a significant monument that bears proof of Moroccan-Roman socio-cultural fusion. Moreover, this archeological site bears memories of great Amazigh kings and personalities like Juba II and his wife Cleopatra Selene II. This center and its monumental patterns testify to a period of scientific research and race hybridity of the Berbers and the Romans. Moroccans hold pride towards such historical monuments that were founded in pre-Islamic periods. Imazighen have also embraced Christianity when it started taking foothold among believers. Furthermore, some amongst them emerged as theologians and as Christian movement leaders. Responding to Islam, Imazighen had also coexisted with Arab Muslims when the call adopted a peaceful approach face to the Berbers.

On the other hand, Imazighen have engaged in a process of borderless economic and sociocultural exchange since immemorial times. Since the first millennium BC, Moroccan Imazighen cohabited with Phoenicians and Carthaginians. This course line of interchange was exemplified through constructing trading ports and centers such as Lixus, Asila, Mogador ..., etc. The long chain of interaction with the different ancient civilizations has been further enhanced from the seventeenth century onwards. During this period of Saadi's rule, Morocco emerged as a modern state, engaging in an unprecedented process of international commercial and economic exchange. That took place with major western powers especially with Britain and later with the United States of America. In this regard, Morocco has been significantly influenced by associating with European and western powers. In the twentieth century, the line of international commercial exchange was reinforced via neo-colonialism. At this period, Europe itself had already undergone important stages of scientific and technological progress. As a consequence, significant output of this progress has been transmitted to the Maghreb countries. Thus, the manners of the colonized were shaped in return and have been subject to significant impact intellectually and materially. Clearly, the liberal and modern character of the colonizer succeeded the military and diplomatic operations of accomplishing the colonial project. Added to this, the western invasion was imbued with messages of adapting the indigenous habits to the requirements of modernism and liberalism. Such approaches aimed at the overall emancipation of humans from the fetters of tradition that prevailed in Medieval ages (Herouach, 2019).

In this regard, Modernism is represented in both materialistic and cultural facades. In other words, it is not only that collection of fancy technological materials inasmuch it is a mode of life. In its concrete form, modernity is represented in all the advanced technological devices the whole world is inclined to use for self-comfort. These tools serve different objectives: global communication, transportation, house chore facilities...etc. Clearly, smartphones, laptops, flatscreen TVs, cars, airplanes, technological fridges, washing machines, etc., are end-results of 
modernity that humanity employs for self-comfort. On the other hand, modernity is embodied culturally and intellectually. In this regard, it refers to a period marked by a questioning or rejection of tradition; the prioritization of individualism, freedom and formal equality; faith in inevitable social, scientific, and technological progress (Foucault, 2019). It also aims at instilling universal values like freedom of thought and freedom of expression. It is represented in the manners of mutual respect, ethics, justice and equality. Modernism as an intellectual movement is, therefore, supposed to reflect the high standards of a sophisticated thought: a thought that embraces world nation differences in terms of color, race, religion and social class and nourishes a spirit of academic controversy and a philosophy of universal communication.

This is becoming a challenge in nations that are guided by a conservative approach. Although religious polemicists and ideologists use modern devices and tools in their daily life, they may display extremism and may be inclined to feed violence against cultural and belief differences. These people could cheerfully employ cars to get to their work office, sit down on an armchair and perform a duty through a high-tech laptop. They use smartphones to communicate with their relatives and family members; they use house chore technological facilitators to lessen the working hours in the kitchen. Nonetheless, they decline modernism as an intellectual movement. In other words, they refuse to embrace the premises that laid the foundation for all the material comfort they enjoy. The core of those premises started with an emphasis on individual autonomy and individual emancipation from the fetters of religious authoritarianism.

Nowadays, there is a growing movement in the Moroccan context that aims at enlightening people on this apparent schizophrenia. Here comes principally the role of numerous Moroccan Amazigh illuminators. Several of these models derive the power of their argument from the Amazigh heritage itself. These luminaries show in public media in a constant manner, leading enlightening episodes, conducting researches, appearing in online interviews and editing critical booklets and books. Examples of these activists are professor Ahmed Assid, the editor in chief of the Amazigh World Journal Rachid Raha, and the codicology researcher Rachid Aylal to mention but a few. These are Moroccan figures who aim at consciousness-raising. They aim at liberating mindsets from religious and cultural deposits that bear seeds of backwardness and ideological vindictiveness. Meanwhile, these luminaries preach worldwide cohabitation and universal coexistence by emphasizing the fact that the premises of this worldview approach lie in the Amazigh tradition itself, a Moroccan enrooted identity. Furthermore, these models refer in their discourses to the demands of the modern-day circumstances that tacitly require a universal approach.

In response, Moroccans are constantly developing immunity against indoctrination, and are acquiring a sense of criticism by getting consciously and unconsciously shaped by the ideals of liberalism. A concrete example of this change is the political decision of Morocco-Israel normalization: a historical win not only for political and economic reasons but also for sociocultural factors. Except for few groups guided by Salafism, Moroccans tend to celebrate this historical event and resume cultural and economic exchange with the Jews. As highlighted above, Moroccans and Jews share common features and historical bonds. Moreover, it is a historical event that witnesses to Moroccan aptitude for socio-cultural transnationalism and universal coexistence. 
All the above-mentioned elements could stand as a rationale behind present-day Moroccan open-minded tolerant and accepting character. In other words, Moroccan people retain flexibility of character inherited from the earliest times of history. Moroccan Berber heritage and its diversity represents a socio-cultural background that involves all sects of society. In addition, Imazighen models and luminaries mentioned-above stand as a background legacy for promoting research, art, social emancipation, economic and cultural exchange and universal cohabitation. For example, Terence is a symbol of innovation and creativity. Juba II represents a period of racial fusion, scientific research, economic internationalism and socio-cultural co-optation. Masinissa is an icon for international pollicization. Tertullian is a symbol for freedom of religiosity from the authority of parsonic institutions. These historical figures may inspire a comprehensive outlook to the entire emancipation of the Moroccan personality socially and politically.

Berber patrimony and legacy could be used to deduce and enhance a set of noble human values. This background legacy need, therefore, be inserted first and foremost in the Moroccan curriculum. Moreover, such deducible themes and values need be emphasized through mass media, TV broadcasting, seminars and conferences, organized workshops, civil society associations and propagandas...etc. Human rights organizations, the political and social elites, educators and teachers, intellectuals and writers; are all required to do their best in orienting the public mindset towards socio-cultural exchange and global cohabitation. In a word, the rebirth of Moroccan heritage and its comprehensive indigenous character could serve as a legitimate base for promoting trans-nationalism and universal coexistence.

\section{Conclusion}

This study shed light on several aspects of the Berber patrimony that justify global cooperation and socio-cultural toleration. The paper presented a comprehensive overview of Berber's cohabitation with the ancient and modern civilizations, with emphasis on Moroccan Imazighen. This paper brought to light major stages of Berber interculturalism with various races and peoples along history. Concrete evidence proved that Morocco has undergone prominent stages of sociocultural and intellectual interbreeding with diverse nations. These civilizations have brought a significant socio-cultural and economic fusion between the natives and the newcomers. This process of exchange started with the Phoenicians in the first millennium BC. Then, it has been enriched upon the arrival of the Carthaginians, Romans, Greeks, Muslims and the twentiethcentury western powers. In terms of belief system, Morocco has embraced different forms of faith from paganism throughout Judaism to Christianity and Islam, added to heresies such as Kharijism and Barghwatan. All the racial populations that were historically involved in the Moroccan social structure, their doctrines and their intellectual schemata, have left a traceable mark on the lives of the natives in terms of culture, folklore, belief system and architecture. Given these historical elements which are part and parcel of the Moroccan identity, Moroccans are more likely to develop a sense of globalization and trans-nationalism.

\section{Endnotes}

Arab World English Journal for Translation \& Literary Studies 
1. Phoenicia was an ancient Semitic-speaking thalassocratic civilization that originated in the Levant region of the eastern Mediterranean, primarily modern Lebanon (Wikipedia, Phoenicia, 2020).

2. Punic, also known as Carthaginians, were a people from Ancient Carthage who traced their origins to the Phoenicians. Punic is the English adjective, derived from the Latin adjective punicus to describe anything Carthaginian. Their language, Punic, was a dialect of Phoenician (Mackay, 2004).

3. Tifinagh also written Tifinay in the Berber alphabet is a script used to write the Berber language. The alphabet witnessed some modification and standardization by IRCAM in Morocco known as Neo Tifinagh: $+\sum\left[\left[\sum I_{0} \Psi\right.\right.$.

4. Kusaila was a 7th-century Amazigh Christian king known for prosecuting an effective Amazigh military resistance against the Muslim conquest of the Maghreb in the 680s; slewed Uqba, returned Kairouan and governed Ifrikiya for five years (Houtsma, 1993).

5. Dihya (7th century CE) was a Berber (Imazighen) warrior-queen and seer who led her people against the Arab Invasion of North Africa in the 7th century CE. Her birth name was Dihya, signifying a beautiful gazelle in Tamazight while Kahina is an Arabic title meaning prophetess or seer or witch (Mark, 2018).

\begin{abstract}
About the Author:
Sofian Herouach is a Ph.D. researcher and a published author. He conducts research in the field of Social Sciences at Sidi Mohamed Ben Abdellah University, Faculty of Arts and Humanities, Dhar El Mehraz, Fes, Morocco. So far, he has works published in peer-reviewed and indexed journals such as Open Political Science and AWEJ. Moreover, he is an active member in the educational sector, teaching ESL in public high school under the direction of the ministry of education, vocational training and scientific research. https://orcid.org/0000-0003-2266-3668
\end{abstract}

\title{
References
}

Abun-Nassr, J. M. (1971). A History of the Maghrib. Cambridge: Cambridge University Press. Cartwright, M. (2016, April 28). The Phoenicians - Master Mariners. Retrieved from Ancient History Encyclopedia: https://www.ancient.eu/article/897/the-phoenicians---mastermariners/

Chafik, M. (2005). A Brief Survey of Thirty-Three Centuries of Amazigh History. Rabat: Royal Institution of Amazigh Cultutre, Center of Translation, Edition Documentation and Communication.

Elder, P. t. (1857). The Natural History of Pliny. London: Henry George Bohn.

Fage, J. (1978). The Cambridge History of Africa (Vol. II). New York: Cambridge University Press.

Foliot, F. (2020, August 31). Bronze Bust of Juba II. Retrieved from World History Encyclopedia: https://www.worldhistory.org/image/12639/bronze-bust-of-juba-ii/

Foucault, M. (2019). Discipline and Punish: The Birth of the Prison (A. Sheridan, Trans.) London: Penguin Books Limited.

Frend, W. H. (2000). The Donatist Church: A Movement of Protest in Roman North Africa. Oxford: Oxford University Press. 
Fyle, C. M. (1999). Introduction to the History of African Civilization: Precolonial Africa (Vol. I). New York: University Press of America.

Herouach, S. (2019). Liberal Feminism Impact on Moroccan Educated Women: Faculty of Letters and Human Sciences, FLDM, as a Field Study. Open Political Science, II(1), 128-152. doi:https://doi.org/10.1515/openps-2019-0014.

Houtsma, M. T. (1993). E. J. Brill's First Encyclopaedia of Islam, 1913-1936 (Vol. VI). Leiden: Leiden Brill.

Howe, M. (2005). Morocco: The Islamist Awakening and other Challenges. New York: Oxford University Press.

Joseph, F. (2003). The Lost Treasure of King Juba: The Evidence of Africans in America before Columbus. Washington: Amazon.

Kagan, D., Ozment, S. E., \& Turner, F. M. (1987). The Western Heritage. New York : Macmillan.

King, A. (2020, September 01). Juba II. Retrieved from Ancient History Encyclopedia: https://www.ancient.eu/Juba_II.

Mackay, C. S. (2004). Ancient Roma: A Military and Political History. Cambridge: Cambridge University.

MacKendrick, P. (1980). The North African stones speak. Chapel Hill : University of North Carolina Press.

Mark, J. J. (2018, March 16). Kahina. Retrieved from Ancient History Encyclopedia: https://www.ancient.eu/Kahina/

Markoe, G. (2000). Phoenicians. Berkeley: University of California Press.

Montagne, R. (1973). The Berbers, their Social and Political Organization. London: Frank Cass and Company Limited.

Niebuhr, B. (2009). Lectures on the History of Rome: from the First Punic War to the Death of Constantine, Volume 2. London: Taylor and Walton.

Numidix. (2017, November 27). Masinissa. Retrieved from World History Encyclopedia: https://www.worldhistory.org/image/7693/masinissa/

Oberman, H. (1974). Luther and the Dawn of the Modern Era: Papers for the fourth International Congress for Luther Research. Leiden: E.J Brill .

Oliver, J. D. (2008). The Cambridge History of Africa (Vol. 1). Cambridge: Cambridge University Press.

Pennell, G. (2003). Morocco from Empire to Independence. London: One World Publications.

Raven, S. (1993). Rome in Africa. Abingdon: Routledge.

Rouighi, R. (2019). Inventing the Berbers: History and Ideology in the Maghrib. Philadelphia: University of Pennsylvania Press.

Sadiqi, F. (2014). Moroccan Feminist Discourses. New York: Palgrave Macmillan.

Saithip, P. (2014, September 14). History of the Beautiful Morocco. Retrieved from Intro to Contemporary Africa: https://sites.psu.edu/afr110/2014/09/24/history-of-the-beautifulmorocco/

Schaar, S. (2016). The Barbary Coast. In A. M. Josephy, Africa: a History. New York: New Word City. 
Sinclair, M. (2017, February 2). A Brief History of the Ancient Roman City Volubilis, Morocco. Retrieved from Culture Trip: https://theculturetrip.com/africa/morocco/articles/a-briefhistory-of-volubilis-morocco/

Stokes, J. (2009). Encyclopedia of the Peoples of Africa and the Middle East (Vols. I-II). (J. Stokes, Ed.) New York: Facts On File.

Terence. (2018, January 22). The self-tormentor (Heautontimorumenos). (R. Frederick, Performer) Publius Terentius, New York, New York, USA.

UNESCO. (1984). Tyre. Retrieved from UNESCO: https://whc.unesco.org/en/list/299/

UNESCO. (2001). Medina of Essaouira (formerly Mogador). Retrieved from UNESCO: https://whc.unesco.org/en/list/753

UNESCO. (2008). Archaeological Site of Volubilis. Retrieved from UNESCO: https://whc.unesco.org/en/list/836

Violatti, C. (2010, December 30). Cyrene. Retrieved from World History Encyclopedia: https://www.worldhistory.org/cyrene/

Weitzman, B. M. (2011). The Berber Identity Movement and the Challenge to North African States. Texas: University of Texas Press.

Wikipedia. (2020, October 25). Phoenicia. Retrieved from Wikipedia: https://en. wikipedia.org/w/index.php?title=Phoenicia\&oldid=985360718 